\title{
SEMIÓTICA DEL DISCURSO Y TEXTO PLÁSTICO: DEL ESQUEMA TEXTUAL Y LA CONSTRUCCIÓN IMAGINARIA
}

\author{
ANTONIO GARCIA BERRIO \\ (Universidad Autónoma de Madrid) \\ MARIA TERESA HERNÁNDEZ \\ (Universidad Nacional de Educación a Distancia. Madrid)
}

\section{La inversión semiótica en el orden de las metodologias críticas: ut poesis pictura}

Los métodos y categorías semióticas de análisis de discursos en la lengua natural han adquirido ya un estatuto definitivo de legitimidad incuestionable. Más frecuentadas, y por lo tanto tal vez aún mejor atestiguadas, son las posibilidades semióticas de analizar discursos artísticos en lengua natural, poéticos y literarios. Nuestra aportación en este artículo tiene el doble objeto de proponer de una parte, dentro de la consideración de la metodología semiótica, la necesidad de extender los análisis más allá de su ámbito comúnmente ensayado de la lengua literaria en sentido estricto de material verbal inmanente. En segundo lugar, tratamos de establecer la posible articulación de una estructura metodológica así constituida, a los textos plásticos de la pintura, objetos artísticos en sí mismos ajenos al dominio de las lenguas naturales (Hernández; García Berrio, 1985).

En relación al contenido de la primera finalidad, la fórmula que nos parece de más urgente adhesión es la que consiste en extender los análisis lingüísticos sobre el texto artístico a su inmediata y necesaria extensión imaginaria-fantástica. En efecto, el texto poético se define no sólo por ser una organización muy especial del material comunicativolingüístico, sino sobre todo porque a partir de esas peculiaridades ver- 
bales expresa y comunica el universo de la imaginación; tanto en la dimensión semántica de sus símbolos como en la estructuración de una peculiar espacialidad fantástica. La poesía, que puede ser definida en su dimensión estrictamente material-verbal como «práctica sistemática de la excepción lingüística" (García Berrio, 1980: 142-145), no agota a nuestro juicio la explicación de sus virtualidades comunicativas sino cuando se apela al trabajo de la imaginación, en el doble espacio de su dimensión expresivo-creativa, como en el de la sugerencia sobre el receptor.

El orden de nuestra explicación actual de la pintura desde la experiencia semiótica de los análisis literarios invertirá, en consecuencia, la naturalidad habitual del viejo lema clásico «ut pictura poesis.» Uno de los lugares comunes más frecuentados en los comentarios literarios a ciertos pintores es aquél que asimila todavía hoy la pintura a la poesía, renovando con variaciones el viejo lema clásico. De los cuadros de un buen número de pintores, se ha dicho y se dirá que son productos y mensajes animados de poeticidad, para proclamar la pulcritud lírica, la delicada efusión medida, de sólido énfasis íntimo. Si en otros momentos los paisajes de Watteau o de Constable pudieron ser calificados como poéticos por la instrumentación plástica de sus contenidos, hoy se oye hablar, del intimismo lírico de Carmen Laffon, por ejemplo; o bien de las más delicadas modulaciones de un pintor tan pobladamente vario como es Lucio Muñoz.

¿Podriamos verlo al revés? ¿Sería más ilustrativo y fructífero? Por lo menos en el caso de nuestro propio comentario, como de quienes llegan a la teoría general estética desde la filología, y la semiótica, la cuestión se presenta con pocas dudas. Se trataría de invertir el viejo lema horaciano, paradigma de este género de símiles — «ut pictura poesis»-, en su alternativa significativa «ut poesis pictura». En efecto, a estas alturas de la evolución científica pudiera antojársele a un filólogo, seguramente que con fundadas razones de objetividad, concluir que la exploración hermenéutica del texto del poema y de su proceso genético-creador está más asiduamente recorrida y más distintamente trazada que la explicación de los arcanos de efectividad estética atesorados en la obra plástica. Es decir, si para Horacio, fundado en la naturaleza más inmediata de la cosa, la explicación de lo recóndito, la poesia, podía facilitarse desde la observación de lo más directo e inmediato, la pintura (García Berrio, 1978), el grado de evolución actual de las respectivas disciplinas semióticas invita, tal vez, a invertir entre pintura y poesía el orden de los términos de diafanidad y misterio.

Vengamos con todo ello al terreno de las evidencias. Cualquier cuadro se propone en su objetividad material como un texto. Haciendo 
abstracción del proceso comunicativo que inevitablemente establece, el cuadro es más inmediatamente objeto que soporte. Y a esa condición objetiva atañen la mayoria de las reflexiones, aclaraciones y explicaciones, aportadas habitualmente por las teorías formalistas y estilísticas. $Y$ no se olvide después de todo cómo el formalismo plástico alemán, con Riegl y Wölfflin, fue precedente y seguramente unas de las causas mediatas del formalismo filológico ruso, de Šklovskij a Tomaševskij; cuestión distinta sea la innegable ventaja después cobrada por los filólogos sobre los teóricos de las artes plásticas en el desarrollo de una hermenéutica del estilo (García Berrio, 1973).

La tentación semiótica de explicar las entidades plásticas desde una teoria semiótica del discurso poético no es nueva, ni carece de logrados antecedentes. El peligro, con todo, es que ese acceso metodológico naufrague y se malogre en la inexactitud de holgados metaforismos. No faltan, en efecto, en la plástica afigurativa moderna casos de auténtica provocación como el de los cuadros de Joan Miró. La condición probadamente gráfico-escritural de la mayoría de sus signos -principio tal vez de su más mencionada debilidad: la reiteración de símbolos y esquemas en el Miró definitivo-induce fácilmente el análisis semántico más inmediato en términos de «lectura. Conviene no obstante, como señalábamos ya hace tiempo, aproximar tales lecturas a los términos más rigurosos y exactos posibles del esquema analítico semiótico, y no utilizar inorgánica y metafóricamente principios y categorias ocasionalmente útiles para destacar este o aquel principio útil del sistema lingüístico de representación, corroborando determinado rasgo estilístico de un cuadro o del sistema plástico de un artista.

El principio de la plurifuncionalidad de los sistemas de descripción para cuadros y obras literarias se basa, a nuestro juicio, en la homología pragmática que regula los sistemas de expresión y comunicación de unos y otros textos, además de las semejanzas estructurales establecidas precisamente por la condición textual de las dos clases de obras artísticas. La más inmediata y más fácilmente comprensible es que cuadro y poema comparten sustancialmente las mismas condiciones de referencialidad icónica. Ambos son intermediarios simbólicos, cuyas respectivas estructuras constitutivo-materiales resultan relativamente arbitrarias y distantes a la naturaleza y morfología específicas de los referentes reales que tienen la capacidad de representar. Tal vez esto sea más comprensible, en principio, para el informalismo y la llamada pintura abstracta - y en general para las tendencias «modernas" del expresionismo al cubismo o el realismo imaginario- que para la pintura clásica, que queda sostenida precisamente en virtud de unos convencionalismos de correspondencia mimética, que en pintores 
como Dürer o Velázquez alcanzan niveles de inmediatez realista verdaderamente sorprendentes.

Sin embargo, aun en estos casos de externa referencialidad mimética mencionados, si se descuentan en el intercambio comunicativopragmático los convencionalismos estrictamente técnicos, tales como los efectos de perspectiva y claroscuro, el sistema de representación material en el plano de un universo de volúmenes, cuerpos y espacios tridimensionales, no deja de ponderar la condición relativamente abstracta de todo sistema plástico de representación. Lo que explicaria los grados tan distintos de saturación artística para la representación icónica, que registran las varias manifestaciones históricas del «arte oriental», frente a las varias escuelas -en sí, a su vez, asombrosamente diferenciadas - del llamado arte occidental europeo.

Absorbidos en cada pormenor especializado de las técnicas de representación en el cuadro más convencionalmente figurativo de Tiziano o de Goya, no deja de sorprendernos la condición autónoma y endorreferencial de aquellos materiales plásticos. Es observación bien trivial, pero no menos significativa, que los valores plásticos de las pinturas en las grandes obras de arte se defienden por su propia capacidad de sugestión textural y cromática y no principalmente por su dependencia y ordenación jerarquizada al conjunto textual del que forman parte, y a cuya significación temática global contribuyen.

Desde esa perspectiva, por tanto, nos hemos inclinado siempre a juzgar superficiales y accesorios los debates entre figuratismo y abstracción; o más en general hemos considerado marginal la polémica en pintura y poesía sobre la declinación del aristotelismo mimético en arte, que registra una quiebra general y progresiva a partir de las revueltas románticas. Sustancialmente los principios constitutivos de la pintura aparecen vinculados sobre todo a ritmos textuales de expresión y de lectura, antes que a necesidades estrictas de representación; lo que hace que no todo cuadro nitidamente figurativo sea apreciado estéticamente más que cualquier propuesta plástica moderna. No es desconocido que el arte moderno en su conjunto ha sido objeto de desorientadas especulaciones del interés comercial. Esto reconocido, no implica necesariamente la descalificación global del arte antimimético y afigurativo como alternativa progresista y positiva en la dinámica de la «serie» plástica.

Lo que desorienta tal vez en la propuesta estilística del arte moderno como globalidad, es que no puede ser formulado en términos de arreferencialidad significativa, sino de arraigada voluntad polisémica. La significación del enunciado abstracto evita deliberadamente la monosemia representativa del arte tradicional. El principio de consagra- 
ción de los varios informalismos plásticos, como el de la poesía moderna, radica más en una amplia ambición que en cualquier forma de restricción comunicativa. A través de la polisemia imaginativa, la libre sugerencia de los materiales plásticos en su manipulación técnica persigue efectos comunicativos más varios y espirituales, más sentimentales y profundos. Saltando sobre la dialéctica de limitaciones que crean en el arte tradicional la desproporción realista entre objetos y medios de la mímesis, el arte moderno trató de situarse en una posición de ventaja comunicativa, apostando resueltamente por una hipótesis de medularidad expresiva. A través de los progresivos desarraigos técnicos que suponen las varias épocas de Picasso, su propuesta de una autonomia significativa de los signos plásticos fue haciéndose más arraigada. El arte moderno, en pintura como en poesía, desgasta el vínculo de la monosemia comunicativa del discurso práctico-conceptual, para ganar en la libertad polisémica de las formas textuales espacios progresivos de evocación sentimental-imaginaria, ámbitos antaño cerrados, o cuando menos relativamente desatendidos por el arte mimético tradicional.

Pero la capacidad polisémica del arte abstracto no se basa tanto, sobre un principio de libertad estructurales absolutas, como se afirma desde las varias poéticas - literarias y plásticas- de la obra abierta, cuanto en la más exigente conciencia pragmática de la comunicación textual. Cierto es que la abdicación del orden canónico de la referencialidad realista contribuye a «abrir» relativamente las posibilidades de sugerencia del texto plástico; ensanchando y potenciando a su vez la colaboración fantástica de los receptores. Sin embargo la postulación de una posibilidad infinita de lecturas del texto artístico, que trata de potenciar el protagonismo en detrimiento de un orden necesario de constitución estructural en el texto como fundamento de la comunicación artística, no ha dejado nunca de parecernos una atractiva paradoja irrealista. Creemos haberlo discutido razonablemente ya para la literatura; y no me parece que la situación sea diferente para el caso de la plástica.

Precisamente son los principios y mecanismos más inabdicables de la «lectura» del texto plástico, los que obligan a conciliar, a nuestro juicio, la polisemia significativa del arte moderno y el indeclinable principio de una raíz estructural en el cuadro. Ningún artista creo que haya alcanzado aún a volatilizar completamente las estructuras de espacialización textual de la obra plástica, a las que ha unido inmediatamente su principio de aproximación comunicativa. El espacio del cuadro, aún más que el del poema, establece automáticamente desde la acción plural de sus constituyentes el cálculo comunicativo de las propuestas 
inerciales de lectura, de los concordados ritmos de visión. Sin ellos, hundido su principio comunicativo, el disciplinado universo de las prácticas significativas excepcionales, que buscan variamente las poéticas del arte moderno, se desvanece en la «agramaticalidad» plástica que las desnaturaliza como objetos estéticos, y en el "sinsentido" semántico-pragmático, que relega el principio artístico de la manipulación intencional a simple casualidad opaca, irreducible a percepción. Así pues, el espacio textual del cuadro, que reconoce ciertamente con el arte moderno una relativa amplificación en sus márgenes de instrumentalización plástica excepcional, no tolera sin embargo la violación real de los principios comunicativo-estéticos, constitutivos del orden de necesidades estructurales inherentes en el lenguaje de la comunicación estético-artística.

Adviértase, sin embargo, que hablamos de «necesidades» entitativas y no de forma alguna de convencionalismo cultural-pragmático. La naturaleza textual del cuadro, como del poema, no se constituye como forma errática, ajena a las peculiaridades síquicas conscientes y subconscientes del hombre, como sujeto de la experiencia estética artística. El poema y el cuadro proponen sus respectivos textos materiales como un espacio significante acotado, bajo la conciencia inmanente de sus límites, precisamente de los cuales se condicionan los principios de coherencia y de unidad, los centros de interés y de propuesta, de interpretación y de lectura. El cuadro, como el poema, se constituye en consecuencia como el dominio espacial del alojamiento simbólico; pero no como un espacio caótico y ajerarquizado, sin reglas de constitución estructural causal. La semántica de los símbolos iconográficos acaece en el cuadro según una regulada sintaxis de la organización plástica del espacio. Esta, a su vez, no es ajena, tampoco - como trataremos de ilustrar más adelante- a los principios constitutivos de la orientación antropológico-imaginaria del hombre en su mundo.

\section{Las correspondencias plástico-poéticas y el esquema semiótico de niveles}

Poemas y cuadros tienen en común, más allá de las más inmediatas apariencias, la estructura material de sus soportes respectivos. Resulta sin embargo curiosa la confusión que se da comúnmente entre criterios como el de la fungibilidad o el de la extensionalidad espacial y materialidad física. Un cuadro, y en esta lógica todavía más aún una escultura, parece siempre al común de las opiniones más inmediatamente material que un poema. Seguramente es asi porque el cuadro impresiona a 
la vez sensitivamente a la vista y al tacto, y porque, en consecuencia, es objeto de las operaciones específicas de ambos sentidos. Un cuadro en último término, se dice, sufre desgaste material; en condiciones desfavorables corre el riesgo de degradarse en su estructura material y desaparecer. En el peor de los casos puede incluso ser destruido por accidente o vandalismo. Pero no se piensa a menudo que otro tanto acaece al poema en su estructura material. El poema en su forma genuina de mensaje artístico-verbal, antes de ser perpetuado bajo forma escrita, constituye una entidad material aún más fungible que el cuadro, y de adquisición no menos sensitiva. Basta al ódo perceptor la existencia en el medio de cualesquiera perturbaciones físicas, para que su transmisión se vea dificultada o incluso impedida por los «ruidos». No creemos que valga la pena argumentar más extensamente sobre un hecho tan evidente como el de la condición físico-material y acústica del poema como enunciado verbal; lo que implica, incluso, su estatuto más puro y genuino, ya que su traslación gráfica escritural es un hecho relativamente ocasional y secundario, en puridad ajeno a la naturaleza de acto verbal de la poesía. Nuestra insistencia en este punto trata solamente de evidenciar la naturaleza falaz de un generalizado prejuicio comparativo entre poesía y pintura, que confunde la naturaleza objetual del cuadro con una supuesta inmaterialidad radical del poema.

El análisis del material verbal del poema ha sido ya suficientemente tratado y recorrido por las metodologías crítico-filológicas de la literatura. Otro tanto puede decirse de la constitución textual del cuadro en cuanto práctica artística. Lo que no se ha hecho corrientemente es relacionar los dos tipos de operaciones del análisis artístico, para constatar en la práctica el paralelismo textual efectivo estructural y genético entre el poema y la obra plástica. Ese cotejo, posible en muchos modos y bajo ópticas variadas, resulta a nuestro juicio particularmente ilustrativo y fructífero bajo la experiencia específica del esquema semiótico.

Las varias escuelas formalistas de Poética lingüística han acumulado a lo largo de los últimos setenta años una insuperable documentación y experiencia sobre los rasgos lingüísticos con peculiaridad estilística muy marcada en el poema. En consecuencia, las tentativas de explicar el fundamento lingüístico de la literaridad y aun el de la poeticidad de los textos artístico-verbales se han proyectado puntualmente sobre fenómenos individualizados en los diferentes niveles de lengua - del fono-acústico al pragmático-comunicativo, pasando por el gramatical y el léxico-semántico-. Bajo esa dinámica inmanente-lingüística, la instancia textual apareció en algún momento como «el nivel de decisión" de las atribuciones de literaridad/poeticidad (Garcia Berrio, 1980: 
145-152); precisamente en la medida en que conjugaba cualitativamente para el caso de la lengua poética, fenómenos individuales de intensificación cuantitativa, como el hipérbaton sintáctico, o rasgos meramente negativos de antitendencia, como puedan serlo las aliteraciones o la rima. En ninguno de ellos se descubrían por sí mismos posibilidades cualitativamente diferenciadas, no ya para fundar sobre ellas el principio de autonomía lingüística, que se requeriría para justificar la lengua poética como sólido desvío «dialectal», sino incluso como articulado y complejo lenguaje autónomo independiente del «estandar» lingüístico-comunicativo.

El libro Enrique Brinkmann: Semiótica textual de un discurso plástico (García Berrio, 1981) aportó una aplicación sistemática y exhaustiva $y$, a nuestro juicio, no meramente tengencial ni metafórica para analizar el conjunto de la obra de un pintor con los métodos y categorías comunes en Semiótica lingüística. Resultaba en consecuencia el cuadro afirmado en su primer nivel sobre unos constituyentes plásticos pre-significativos, como los fono-acústicos de la «segunda articulación» en el lenguaje. Peculiaridades muy características en Brinkmann de "collage" de papeles y "grattage» en la constitución del fondo de sus soportes plásticos. Singularidades cromáticas también muy características en este pintor, como las calidades de sus ocres. Rasgos personalísimos de su manejo de la línea en permanente ondulación y zigzagueo en el dibujo a plumilla incorporada en sus técnicas mixtas, etc., etc. Todo ello eran elementos expresivos previos a la articulación conceptual de la expresión plástica, como los varios efectos fonoacústicos de aliteraciones, rimas y colorido vocálico puedan serlo respecto a la significación verbal. Pero elementos presignificativos en sí mismos a su vez poderosamente autorreferenciales, los plásticos como los verbales, dentro de la peculiaridad del «mensaje» artístico en la función poética. Unos y otros, los presignificativos plásticos del cuadro como los fonoacústicos del poema, participan, del carácter de «modelización secundaria" que hace de esas formas previas, relativamente indiferentes en la significación práctica-conceptual del lenguaje, signos poderosamente necesarios y endo-deícticos en su articulación concreta dentro del enunciado artístico.

Pero Brinkmann practica un estilo muy concreto de pintura preciosista, en la que esa condición autorreferencial de los constituyentes adquiere un protagonismo intencional decisivo. El mismo efecto de focalización sobre el valor casi autónomo de las propiedades estrictamente plásticas se registra en pintores de las más variadas tendencias conceptuales, desde Juan Gris a Salvador Dalí en los mensajes surrealistas, o Antonio López García, Carmen Laffón o José Hernández, por 


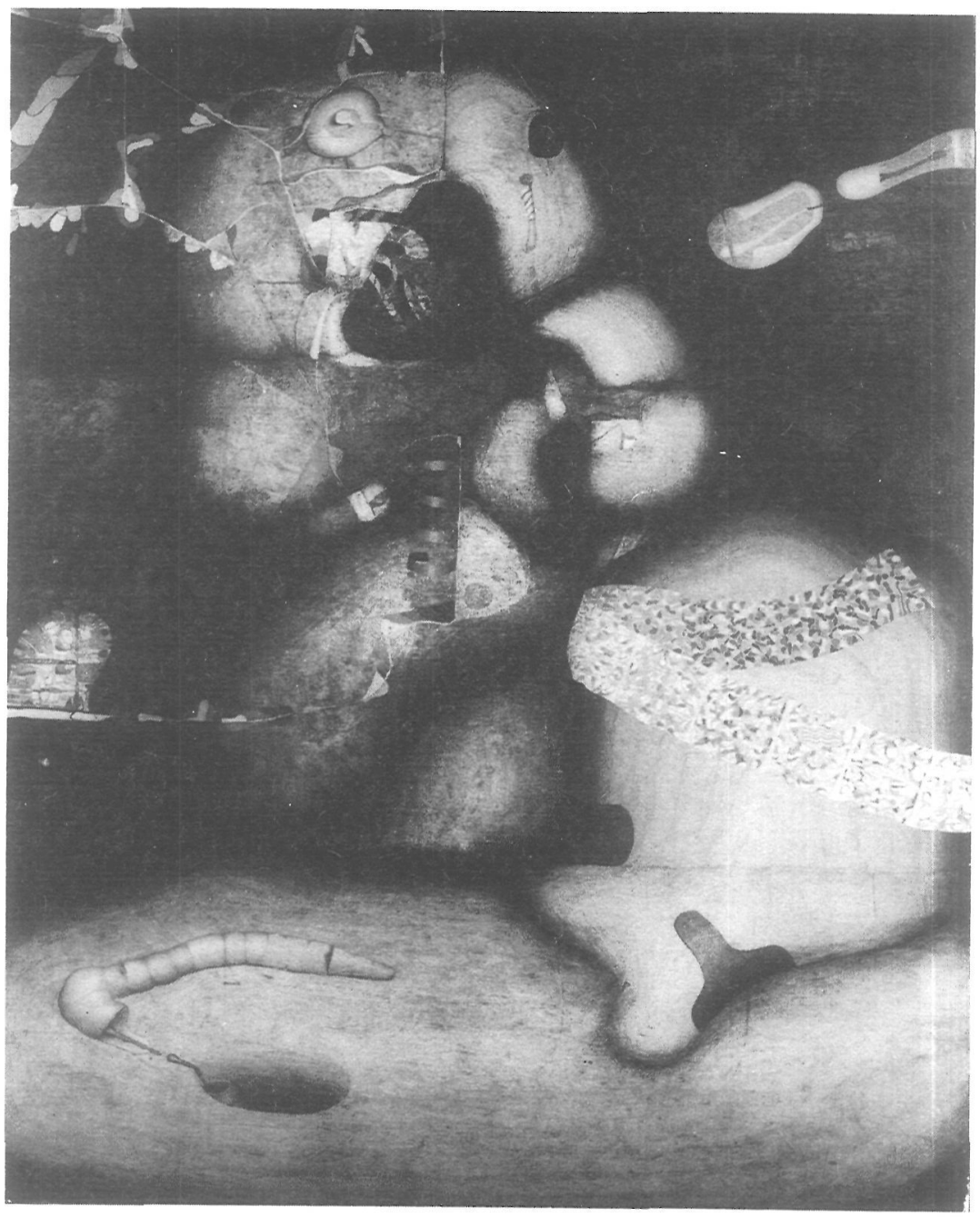

ENRIQUE BRINKMANN «Después del parto» 
mencionar sólo a tres de los más importantes representantes de las varias tendencias en la figuración realista española —objetivista, lírica, mágica, etc. - Por su parte, las escuelas abstractas han convocado todavia más expresivamente el protagonismo de los materiales pre-significativos. Recuérdese el caso de su excelente instrumentación estética por el malogrado Millares, figura destacadísima en el grupo El Paso, hipertrofiando las capacidades poético-endorreferenciales del material plástico. En la pintura española es sin duda Antonio Tapies el ejemplo paradigmático de explotación sistemática de esa condición específica del material. Actitud estilística pionera y extremada en el caso del famoso pintor catalán, que conlleva para la obra plástica como texto exorreferencial los consiguientes riesgos de opacidad intransitiva.

La neutralidad funcional de los constituyentes prefigurativos en el caso de la plástica es casi tan imposible como en el de la poesía. Las varias pretensiones de signo dadaista, o las de reciclaje artístico de objetos naturales y aun de uso común degradado en el caso de los cuadros de Picabia o de las más recientes esculturas de Joan Miró, no dejan de ser en su ineficacia estética paradójicos argumentos «a contrario", de esa verdad tradicional inmovible de la pintura como «arte beila». Y esta condición se oculta y se cumple, incluso, bajo las apariencias más desfiguradas. Pensemos en el caso de una pintura de significantes tan agresivos como lo es la de Luis Gordillo; sin duda uno de los mayores protagonistas de la importante renovación plástica española de los últimos diez años.

Sin embargo es de ese mismo nivel de los constituyentes mínimos presignificativos de donde, a nuestro juicio, arrancan algunos de los más logrados acentos plásticos de este pintor. El poderoso impacto visual de su obra radica en buena medida en la pulsión elemental del grafismo, así como en las sugerencias cromáticas analizadas. $Y$ esto con el carácter previo, incluso, a su articulación e inserción en las dialécticas más plurales y complejas de los constituyentes plásticos de la significación elemental. Piénsese, por ejemplo, en la vigorosa capacidad de sensación plástica derivada de los componentes presignificativos, que ofrece inmediatamente una de sus últimas y más logradas series, la llamada «Mosaico».

Pero precisamente pensando en Luis Gordilio cabe, aún mejor que en otros pintores, expresar la necesaria dinámica natural según la cual esos constituyentes teóricos presignificativos cobran estado real de conciencia estética. Esta transformación se logra a través de una dialéctica elemental y fluida hacia la consolidación en formas sustantivas, singulares, llamadas a constituirse en ingredientes causaies de la significación compleja del texto clásico. La capacidad superior de Gordi- 
Ilo, lo que le otorga un puesto de excepción en la pintura moderna española, es su inagotable capacidad de producir morfemas variados y autónomos. No hablamos todavia aquí de la integración de esas unidades mínimas significativas en piezas lexémicas de figuración semántica, ni en unidades simbólicas de articulación mítico-imaginaria. Aludimos por ahora al plano inmanente y estrictamente gramatical de la estructuración del discurso, donde resulta proverbial la fertilidad de hallazgos morfológicos de Gordillo y sobre todo su incesante renovación de formas. Todo lo cual se hace a base de una inconfundible caligrafía plástica de madurez personal, que no se adhiere, sin embargo, a estructuras repetitivas. Adelantemos, por ahora, que esa cierta fidelidad continuista a un determinado perfil morfológico-estilístico, que Gordillo no conoce en sentido estricto, resulta sólo la consecuencia de su propia riqueza imaginaria y del constante trabajo síquico del autor en la configu ración plástica de sus estados subconscientes.

El doble plano gramatical y léxico-semántico sobre el que se articula la integración textual de la morfémica plástica, encauzada por la retórica iconográfica en la tradición clásica de la pintura, define privilegiadamente el perfil estilístico de los pintores que alcanzan a personalizar con vigor su expresión plástica. En el caso del mencionado estudio sobre Enrique Brinkmann, se analizaba con toda propiedad la existencia de un conjunto de invariantes morfémicas, cuya combinación en sintagmas de variada titulación lograba simultáneamente una positiva variedad de realizaciones sintácticas. Estas, a su vez, permitian considerar el universo textual del autor como un rico agregado de inesperados morfemas característicos. De otra parte, la misma condición relativamente cerrada de los inventarios plásticos morfológicos, así como la práctica sistemática de unos paradigmas muy regulares combinatorioconstructivos - también relativamente cerrados- decantan en Brinkmann un perfil visual de constantes plásticas reconocibles como caracteristicas.

El caso privilegiado de Luis Gordillo extrema hasta el límite estas relaciones dialécticas entre la multiplicidad de los constituyentes morfológicos del sistema, que determinan su riqueza plástica, y la regularidad paradigmática de sus rasgos constitutivos morfémicos y de sus reglas de combinatoria sintáctica, constitutivas del balance estilístico personal. En tal sentido, pocos pintores en el momento actual pueden ofrecer un sumario de constituyentes plásticos a la vez tan múltiple y tan acusadamente personal como este gran pintor sevillano.

El problema se plantea de otro modo, por supuesto, en el caso de la pintura con vocación de referencialidad realista. En la rica escuela del realismo español actual un nombre sobresale con unánime aceptación. 


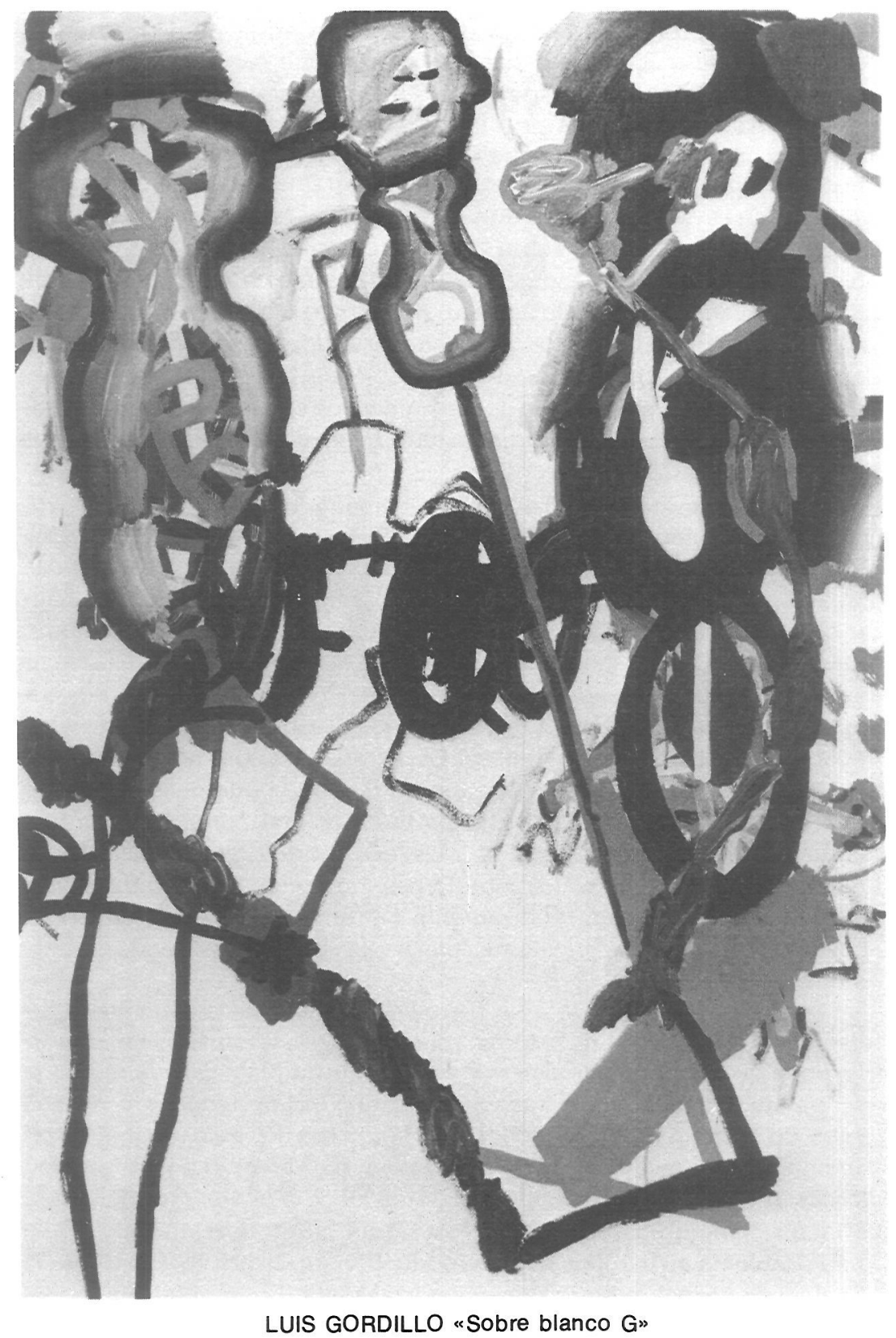


Se trata de Antonio López García, que puede ser propuesto tal vez como uno de los más grandes pintores de la actualidad internacional. En su obra, solidísima y cautelosa, no pródiga de variantes, sino concentrada en progresivos logros de la veracidad plástica, triunfa la implantación natural de una realidad, que se quisiera liberada de toda mediación interpretativa o de cualquier residuo de servidumbres técnicas materiales.

El marco de la verosimilitud plástica reajusta a un esquema mucho más cerrado de posibilidades morfológicas-sintácticas estas obras realistas. En tal sentido, las mismas licencias oníricas de Antonio López sobre su hiper-realidad arrojan el inevitable contagio de unas poéticas alternativas, las de la abstracción contemporánea. Esa contaminación se traduce, a nuestro juicio, en las posibilidades de propuesta visual mucho más pobladas y dinámicas. Podemos afirmar, en síntesis, que la maestría de Antonio López, bajo su apariencia más inmediata de valores plásticos garantizados de antemano, se acoje tal vez a los mismos azarosos límites que las más sólidas muestras de las vanguardias plásticas contemporáneas. Conocida la libertad de aportaciones plásticas de las poéticas polisémicas, la disciplinada monosemización realista de Antonio López exige seguramente del receptor un grado de creencia y de fidelidad, tal vez ya difícilmente practicable para la constitución antropológico-fantástica de los individuos en nuestra edad tecnológica.

La libertad del experimentalismo sintáctico en la plástica moderna, al abdicar en las reglas más puras de armonía compositiva las demandas limitadoras de la verosimilitud realista, inaugura un panorama de productividad estética innegablemente rico. Los viejos atisbos de Mondrian se abren y enriquecen a la iniciativa sensible de las variantes modulares. Se trata de una conciencia plástica regularizada sobre combinatorias del módulo, que, bajo otras apariencias, tal vez nunca haya dejado de ser una constante en la articulación dispositiva de la pintura de todos los tiempos. Por su parte, Luis Gordillo ha sabido acoger rigurosamente el fondo más riguroso del experimento, que practica con tenaz asiduidad. Bien que matizando con fluidez la encar nadura semántica de las unidades modulares de representación. De tal manera, su obra se ofrece bajo una inmediatez más carnal y biológica, que le permite experimentar con más riqueza plástica con la racionalidad aséptica de las posibilidades retóricas incluidas en la combinatoria modular.

Los morfemas plásticos se configuran en la realidad de la obra como formas léxico-semánticas reconocibles, como recorridos característicos hacia la galería simbólica que define el universo de cada estilo personal. Con Miró se introdujo en la pintura española y europea 
un género de esquematismo aislacionista de catálogo léxico-semántico, que no deja de suscitar importantes desconfianzas sobre su primitivismo conceptual y sobre su monotonía reiterativa, las cuales no se ven enjugadas completamente por la novedad de su estilo como propuesta plástica. En tal sentido, nos parece que diversas instancias individuales en la pintura moderna española ofrecen ejemplares esfuerzos para articular los lexemas más elocuentes y expresivos en esquemas de integración plástica con probada eficacia de incorporación semántica. Uno de los casos más elocuentes, dentro del panorama de la mejor pintura española actual es el de Antonio Saura. En sus criaturas, el inventario léxico-semántico de unidades reconocibles $\longrightarrow$ ojos, sexos, símbolos indumentarios, etc.--, contribuye a articular universos textuales de muy eficaz construcción, de agónica expresividad, partiendo de una sobria evidencia singular.

Parece, en consecuencia, que la libérrima informalidad del arte moderno, tantas veces invocada, lejos de ser una licencia improductiva o un signo de impotencia ante las exigencias disciplinadas de la verosimilitud realista, con su código de limitaciones férreamente establecido, se nos ofrece como uno de los grandes pasos de la productividad artística para ensanchar la experiencia estético-visual. Es un hecho innegable que a ello contribuye la eclosión liberadora de una cerrada retórica iconográfico-morfémica, la cual operaria sobre la densidad de unos nuevos inventarios donde se ensaya la multiplicidad de formas estéticas asimilables. Es igualmente una realidad incontrastable, que una sintaxis de abierta combinatoria modular ensancha aún más la riqueza del universo de sensaciones plásticas, hasta promover desarrollos ilimitados.

Ya hemos señalado antes cómo esa aspiración general moderna a la liberación y apertura de los inventarios cerrados, morfológicos y sintácticos, de la iconografía clásica, se perfila bajo el contagio de los desdoblamientos excepcionales y de las presencias de lo inverosímil onírico en la obra de López García. El riesgo, exagerado en la conceptuosidad característica de pintores surrealistas como Dalí o Magritte, se extiende con seguridad de fórmulas muy logradas en el bello realismo mágico de José Hernández, quien lidera en España una numerosa tendencia con importantes cultivadores. Hernández opera ciertamente sus propuestas de liberación semántica de la realidad sobre el mismo principio de distanciada tensión inusual entre los «semas» constitutivos del complejo asociativo metafórico, en que Reverdy y Breton creyeron ver formulada la pretendida originalidad de la «magen" surrealista. El recurso se halla implícito siempre, no obstante, en el principio de toda construcción metafórica; acrecentando su capacidad de descubri- 


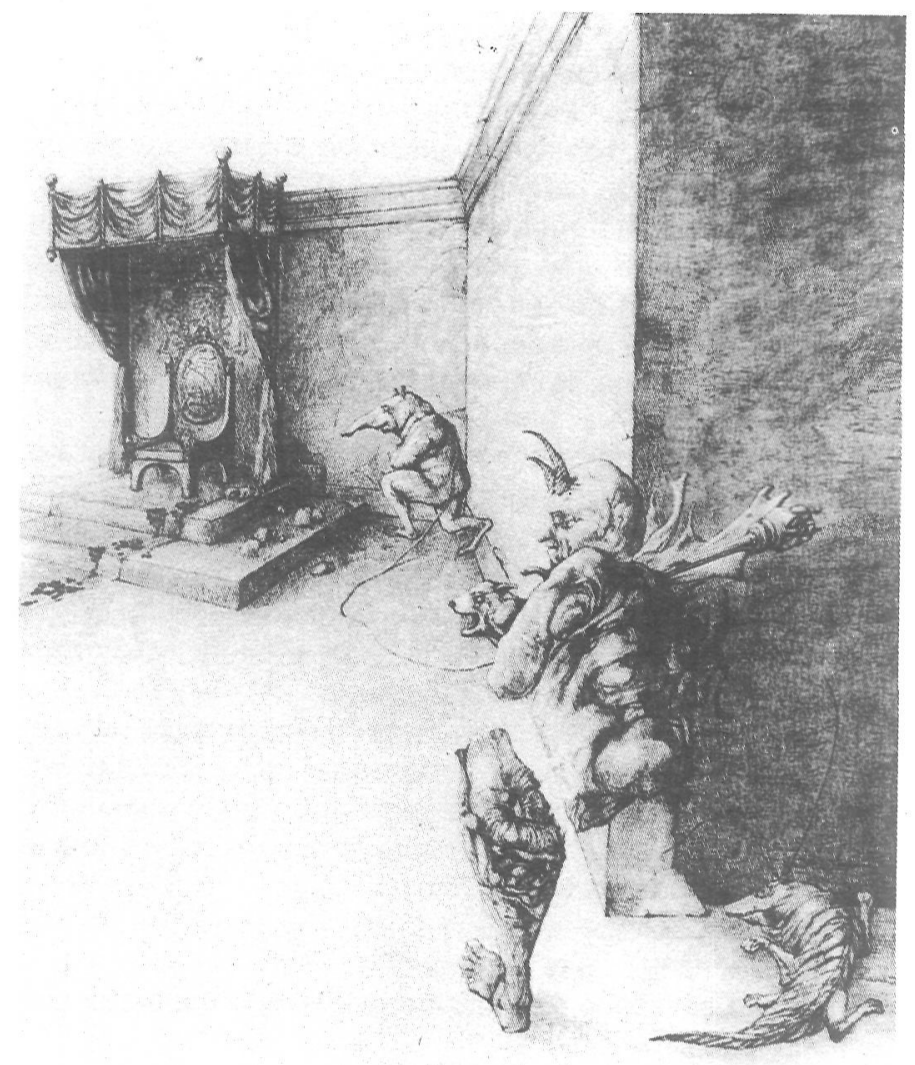

JOSE HERNÁNDEZ «Datos para una autobiografía» 
mientos inusuales bajo la distorsión catacrética del conceptismo barroco.

Hace tiempo nosotros tuvimos ocasión de establecer la filiación metafórico-barroca del difundido principio de la imagen surrealista; precisamente con la ilustración de ejemplos muy caracterizados en la actual escuela andaluza de realismo mágico pictórico (Hernández; García Berrio, 1981). No obstante, más allá de las innegables capacidades de delicia plástica, las posibilidades de dispersión errática de la combinatoria onírico-metafórica del realismo fantástico, no podrán liegar nunca a aproximarse a las posibilidades de renovación y sorpresa inherentes al rico mundo de sensaciones del informalismo y las prácticas abstractas. Limita en este sentido al realismo fantástico su irrenunciable adhesión al sistema de representaciones últimamente miméticoverosímil.

Como esperamos haber demostrado, la analítica de la obra plástica en los términos habituales del esquema semiótico permite asumir los conceptos usuales en el género de análisis formalistas y estilísticos de las artes plásticas. Puede incluso aportar aclaraciones a muchos problemas en términos más ajustadamente rigurosos e ilustrativos de los que son posibles para los análisis tradicionales. La misma propuesta de los niveles analíticos habituales a la semiótica del discurso verbal - fonológico, morfológico, sintáctico, y léxico-semántico-, ofrece por sí misma posibilidades de ordenación categorial de los constituyentes del texto plástico no sólo inéditas, sino sobre todo poderosamente discriminativas para la fijación de los constituyentes en su amalgamada estructura estética. (Bobes Naves, 1985).

\section{El texto: nivel estilistico de decision estética. El esquema textual}

Todos los caminos de la comunicación articulada convergen en el texto. Al texto plástico, como al poético, conduce en definitiva el conjunto de rasgos pecularizantes examinados hasta ahora por nosotros en el dominio de los varios niveles semióticos. Es el texto el que otorga sentido a los estilemas individuales. En la voluntad de afirmación unitaria de su estructura conviven todas las trazas de solidaridad, todas las marcas de la significación global unitaria, estructurales y temáticas. Es el texto un universo de representación plástica; y los márgenes del cuadro no vienen determinados por las afueras de su entorno textual, contra las apariencias más elementales. La gravitación del centro sobre la totalidad de su estructura pondera un sistema de convergencias congruentes. La identidad estética y comunicativa del cua- 
dro, como la del gran poema, arranca de la condición unitaria de su principio de afirmación, del si entitativo, que le confiere sustantividad existencial. Todos los caminos de la pintura llevan al cuadro. Todos los procedimientos plásticos, los rasgos singulares de representación pictórica bajo el despliegue de sus varios niveles gramaticales conducen al texto como unidad cualitativamente nueva, como producto artístico de creación.

El mencionado libro sobre Enrique Brinkmann partía de la anterior convicción sobre la convergencia en el texto, como nivel de decisión peculiarizante, de las varias desviaciones estilisticas individuales. Se advertirá que se trata de la misma tesis que anima nuestro punto de vista formalista, preimaginario, de la esteticidad literaria o poética de los discursos artísticos en lenguas naturales, en términos de «práctica sistemática de la excepción lingüistica». Una práctica que encuentra en el texto su nivel de decisión cualitativa y que proclama, en consecuencia, el principio de necesidad no constituyente de los rasgos específicos de esteticidad para el texto artístico. Explicación que se opone a las difundidas propuestas pragmático-convencionalistas, las cuales invocan la condición de arbitrariedad y relativismo como razón constituyente de los principios del sistema estético de las artes.

El cuadro como texto proclama ciertamente y sobre todo el predominio de la dispositio, armonizando y combinando el conjunto de los constituyentes icónicos, provistos por la inventio iconográfica en la pintura tradicional y por la creatividad de los nuevos moldes estéticovisuales en la peculiar semántica de la pintura abstracta y de los informalismos. La elocutio pictórica atañe a las singulares virtualidades de la caligrafía plástica de cada pintor. Sería como su sistema de conversión y traducción de las representaciones semánticas individuales a las formas plásticas que las transfieren sobre el soporte textual del cuadro. Obviamente el cuadro valioso, ni como objeto-resultado ni como proceso genético se constituirá como un simple agregado estático de operaciones, según las que teóricamente quedan distinguidas en la útil tripartición retórica.

El esquema retórico ha descubierto siempre, y en especial en la historia más propia de su funcionamiento como explicación científica del discurso, sus debilidades metateóricas en cuantos casos se lo ha querido radicalizar, aplicándolo bajo el ideal del compartimentalismo estático. Sin embargo la dinámica producción de sentido, verbal o plástico, impone considerar la tripartición retórica sólo como principio de referencia. En la práctica real de la producción del texto las tres instancias retóricas se alicientan recíprocamente y se presuponen. Las interfluencias son continuas; inesperados los estímulos y las contami- 


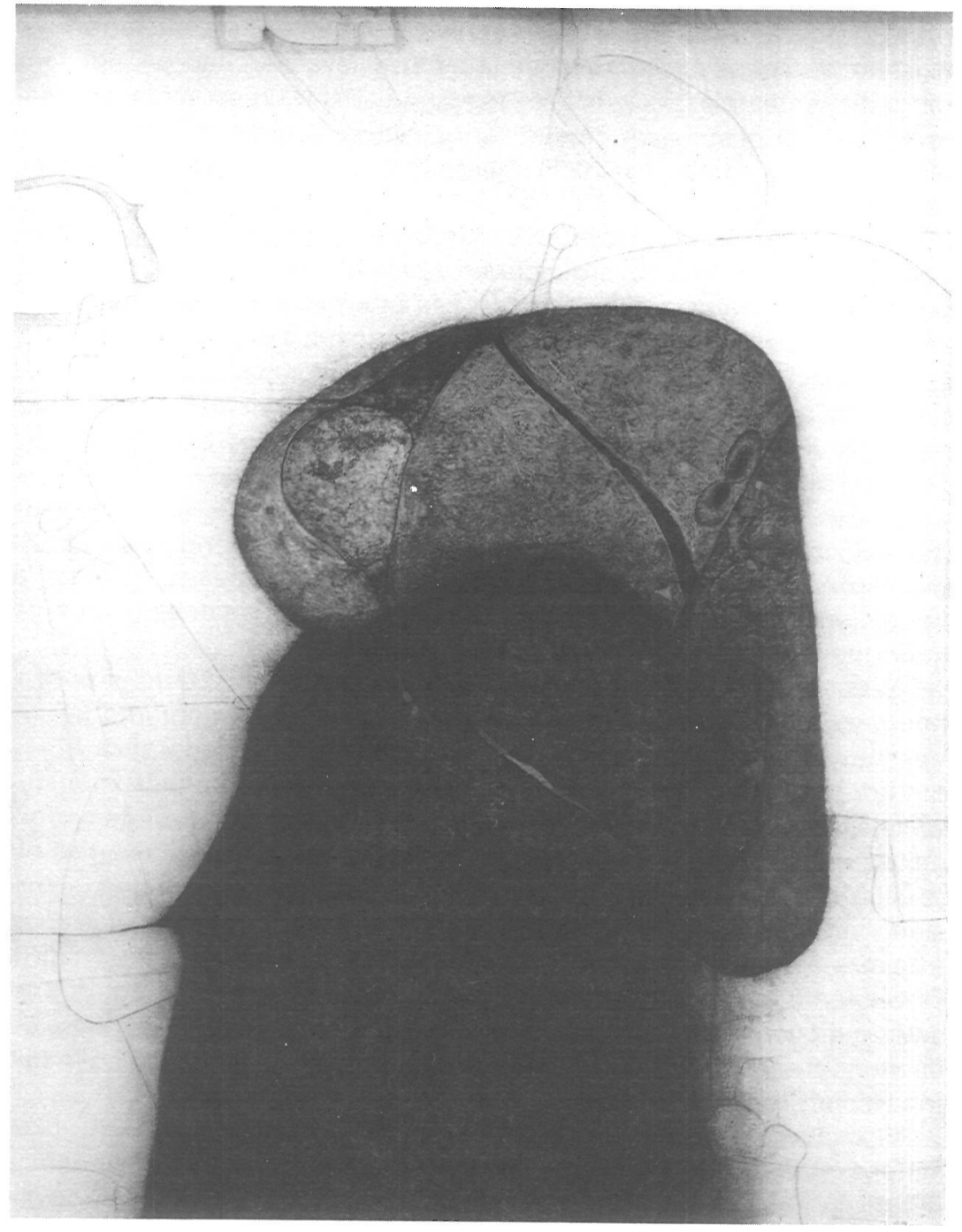

ENRIQUE BRINKMANN «Figura» 
naciones. Todo ello desencadena y anima los desarrollos transformacionales, las estructuras de transición y compromiso, los espacios de necesidad metateóricos.

La analítica de la estructura textual en los cuadros de Brinkmann permitía descubrir sistematismos insólitos, inconscientes incluso para el propio pintor. Por ejemplo, una constante ternaria gobierna la organización estructural de todas sus obras. Puede pensarse tal vez que ello se deba, como en los cuadros de personajes de Antonio Saura, a la coincidencia con los tres espacios constituyentes del retrato: cabeza, busto, y fondo. Pero esa tripartición invade también otros ámbitos y temas plásticos, en los que la estructura tripartita del retrato no tiene por qué ser operante. En los cuadros de «superficies» de Brinkmann, espacios caprichosos de una peculiar epidermis onírica, por ejemplo, la sistematicidad constructora del esquema ternario se impone también inexorablemente. A su vez, cuando Antonio Saura elige el módulo de compartimentación espacial para sus innumerables variantes de «El perro de Goya", está constatando idénticamente la razón ternaria en la estructura de orden dialéctico del espacio, fielmente transmitida a su consolidación concreta en la estructura textual del cuadro.

El análisis sicológico y antropológico profundo de estas peculiaridades de la construcción textual no puede ser objeto de este artículo. La índole de tales consideraciones no se ajusta exactamente a la órbita de intereses y capacidades de una teoría semiótica estricta. Sin embargo no cabe duda que de su constatación y valoración adecuadas pueden deducirse quizás las más interesantes consecuencias a que deba aspirar el análisis crítico del arte. Retornemos una vez más al caso singular de Luis Gordillo. En sus cuadros todo negaría cualquier pretensión de la estructura ternaria observada en nuestros ejemplos anteriores. La provocación espacial de los textos de Gordillo se ve muy frecuentemente planteada y resuelta como el resultado de una dinámica dual de masas enfrentadas, entre las que se tienden todos los puentes de compensación espaciales y de mediación dialéctica. Se comunica de esa manera seguramente, a través de ese esquema de espacialidad, un universo emocional de mayor inestabilidad dramática, de más permanente zozobra que el de las sintesis plásticas equilibradas en la dialéctica ternaria. Todo lo cual no resta sin embargo dramatismo activo a la obra de Saura, ni atormentada sugerencia a las formas de introspeccion digestiva de Brinkmann. La dualidad estructural de los cuadros de Gordillo expresa y comunica al tiempo su permanente esfuerzo para el rescate postural al plano de afirmación consciente del inextinguible fondo de enigmas subconscientes que pueblan la espacialidad nocturna. Pero el tratamiento estrictamente lingüístico de los 
esquemas textuales impone por ahora demorar, a este nivel, las consideraciones relativas a la traslación de las peculiaridades estructurales del texto a términos antropológicos-imaginarios.

Aunque son muchos los pintores que suelen insistir en que en su obra predomina sobre cualquier otro el valor plástico visual; ni siquiera en esas mismas reclamaciones se alude conscientemente al texto material como objeto acabado, cerrado en sí mismo. Es evidente que ni los más ensimismados ejercicios de expresión plástica dejan de constituir, incluso involuntariamente, prácticas de comunicación estética. La reacción a que nos referimos, constituye en la mayoría de los casos una inmediata y honrada manera de desmentir las frecuentes elocubraciones críticas, ajenas a la pintura como problema y ejercicio específico. Es comprensible, además, que el artista plástico reclame de esta forma todo el respeto que merecen sus capacidades y experiencias especializadas, que se ven movilizadas para la ejecución de la gran obra artística.

Resulta evidente sin embargo que el valor del texto plástico, como el del poema, no puede venir restringido a su mera relevancia objetual. Por su estricta dimensión material, el cuadro aporta el esquema textual imprescindible para un acto de comunicación estética, donde las capacidades conceptuales y sobre todo los poderes activos de la imaginación tienen un protagonismo decisivo. El entendimiento artístico del cuadro, como el del texto plástico, incluso bajo las más persuadidas proclamaciones de inmanencia, defiende y justifica la razón de ser última de sus capacidades estéticas, entendiendo el texto como un principio abierto de comunicación.

Actualmente tal vez las tareas más urgentes e interesantes para el análisis textual del arte consistan en vincular adecuadamente el esquema material del texto con el conjunto de las representaciones semánticas complejas del mismo en tanto que unidad construida, expresada y comunicada. En ese tipo de trabajo, las escuelas formalistas y el modelo de análisis históricos y conceptuales han recorrido por lo común caminos bastante distanciados entre sí. Incluso han predominado los antagonismos y malentendidos sobre la voluntad recíproca de comprensión complementaria. Los esfuerzos de la estilística literaria para vincular las peculiaridades del contenido a las pautas y a las desviaciones textuales de la forma se corresponde ciertamente, en este ámbito, con el importante recorrido formal-conceptual aportado desde $\mathrm{Pa}$ nofsky y, en general desde las metodologías iconográficas. Sin embargo nos parece que una y otra vertiente de la critica tienen todavía pendientes importantes reajustes en el plano de las correspondencias de los estilos artísticos con la expresión de los contenidos correspon- 
dientes. Sobre todo en este momento han de resolver además la traslación de las peculiaridades formales del texto a una estructura antropológica del comportamiento imaginario.

De esta manera los rasgos constitutivos del texto artístico, inventariados en otros momentos como parte de un estilo personal, deben ser interpretados, en nuestra opinión, según una sintomática de impulsos imaginarios de orientación espacial. Esas tendencias contarian en el tipo de movimiento de espacialización de la sintaxis del texto con una de sus formas privilegiadas para simbolizar el género de sensaciones fantásticas, que se tratara de sugerir. Asi por ejemplo, la positiva tendencia centrípeta y la inclinación a proponer planos de profundidad, observable en común en las obras de Brinkmann y Gordillo, deberia verse interpretada como manifestación de la tendencia fantástica a la representación imaginaria de sensaciones relativas a la reconcentración positiva o negativa; ya sea en el dominio tutelado y seguro del ámbito, como en la sugerencia espacial y amenazante del cerco negativo.

El esquema textual del cuadro, en consecuencia, representa un espacio privilegiado de propuestas materiales, las cuales son tantas otras pistas de la expresividad subconsciente del emisor, e itinerarios de lectura por los que discurren las respuestas estéticas de la recepción. Un espacio necesariamente acotado, un campo de propuestas ejemplares y paradigmáticas que condensan, más que aislan, una selección ejemplar de la estructura del mundo a juicio del pintor. Sobre esa pista se dejan trascender algunos de los más esenciales símbolos en la representación subconsciente del universo, como también algunas de las tendencias subconscientes a través de las que los seres humanos manifiestan el orden de su orientación imaginaria.

\section{Del esquema textual a la significación fantástica: la Sintaxis ima- ginaria}

Si el resultado textual del cuadro como unidad de armonías y convergencia de variedades puede predicarse en universal como el «momento" regulador, en la suma resultante de los varios sistemas parciales de configuración constructiva de la obra, sera en ese inextenso y expansivo espacio donde quedan afirmadas las propuestas e insuaciones parciales que lo conforman. A él habrá que adjudicar en todo caso la condición lograda o frustrada de cualquier proceso de consolidación plástica. En relación con ello, la crítica de los textos literarios empieza a reconocer ya en los últimos años la limitación de las explicaciones exclusivamente semiótico-lingüísticas sobre los arcanos habituales, 
objetos ultimos de las tareas de explicación de la obra, que son la «literaridad" o la "poeticidad", matrices estéticas de la entidad artística de la obra de arte verbal. La definición en términos exclusivos del «material» artístico del texto, por más refinadas y extremadas categorias y estrategias analíticas que la funden, no resulta satisfactoria. $Y \sin$ afán polémico, añadiríamos incluso que, si tal es la situación de insuficiencia para la Poética del material verbal literario, aun después de complejísimos desarrollos de la linguistica, de la narratología y, en general de la hermenéutica del texto literario; por tanto más menesterosas han de juzgarse aun las estilísticas del texto plástico. Estas atienden también exclusivamente a la explicación de los valores de esteticidad ateniéndose sólo a los rasgos peculiares deducibles desde una poética de los materiales.

Preciso ha de ser, una vez más, ascender de nuevo a la Crítica del juicio kantiana para recuperar, desde allí, la exacta y completa dimensión del panorama en torno a la manifestación y fundamento del parecer estético. Son algunos, que no demasiados ni con demasiada frecuencia, los historiadores de las diferentes estéticas particulares, de la literaria como la de las artes plásticas, que han recabado con clarividencia el estímulo kantiano en la génesis decimonónica de las varias escuelas formalistas. En verdad que la inmediatez del ejemplo aicanzo de modo más intenso y sensible a la escuela formalista alemana de las artes plásticas que a la rusa de críticos literarios, clarividentes iniciadores de los varios movimientos formalistas y estilisticos que han nutrido lo más fructífero, representativo y granado de la crítica literaria en el siglo XX. Ciertamente la reclamación kantiana de un género de necesidades estructurales en la entidad objetiva del ente belio, natural o artístico, objeto del juicio, aporta el salvoconducto más autorizado para los varios formalismos.

Pero no se puede olvidar, y la urgencia y dificultades de la tarea han forzado sin embargo el silencio hasta hace muy poco tiempo, que la exigencia objetiva kantiana se corresponde y extiende a un indefectible requisito de acoplamiento subjetivo. Es la perfecta incardinación y ajuste de la estructura del objeto artístico en las estructuras humanas de percepción y estimación cognitivo-sentimentales, lo que convalida definitivamente la especificidad estética de las estructuras formales del objeto artístico. Se venía a renovar así desde el tratado kantiano, fundador de la estética contemporánea, la secular exigencia, arrancada en la antigua teoría del «placer de reconocimiento» vinculado por Aristóteles a los mecanismos más responsables de la imitación.

Recordar estos pareceres -y con ellos tantos otros posibles y autorizados- sitúa, como redescubrimiento de un universal de validez 
explicativa a las actuales propuestas de la Poética de lo imaginario, tal y como desde Jung y la escuela francesa de Bachelard y Durand (Durand, 1983) se ha propuesto recientemente para sacar a la critica literaria de su estado actual de crisis y perplejidades formales y analíticas. El cuadro, como el texto verbal, encuentra desde luego en las peculiaridades formales de su estructura material inmanente los requisitos objetivos de su esteticidad; pero es preciso trascender, deducir y convertir tales peculiaridades formales de su constitución textual inmanente precisamente en términos de un esquema de comunicación que proyecte el cuadro, el texto material artístico, en la doble dimension de su génesis y su recepción. Las estructuras formal-objetivas del cuadro no constituyen en ultimo término sino la huella de una representacion sígnica de su autor, que traduce pulsiones subconscientes como ritmos espacializados en el texto de discurso material. Mirado desde la vertiente receptora, el texto se configura como el instrumento de mediacion portentosa de esos mismos ritmos, presentidos y necesitados por el espectador como un reconocimiento imprescindible de sus más íntımos mecanısmos de orientación, actuación y expresión sígnica y piologica.

El arte precisa de toda esta trastienda imaginaria para legitimar su suplimidad, de otro modo injustificable. Despojado de esa condición portentosa de soporte de la ilusión y sin la identificacion de unos ritmos imaginarios privilegiados, el cuadro se aplasta y trivializa en la menesterosidad de sus causas materiales y en la condicion arbitraria de sus convencionalismos de factura. La pintura, como el poema, deleita hasta subyugar e induce a confidenciales solidaridades infinitas, en la medida que traduce a espacialidad convencional el universo de ritmos móviles de orientacion antropologica del ser humano. El rapto ascensional, el abismamiento depresivo, la concordia movil de fluctuaciones vagas, Isocronas, convergentes; el encuentro polémico del embate, la efervescencia de la vibracion convulsa y la sugerencia de ámbitos de acogida y de acecho hostil como fustigación enervadora (García Berrio, 1985). Desde la pluralidad de sus imprescindibles constituyentes materiales, palabras y ritmos, formas y colores, el poema y el cuadro consolidan el espacio de unos ritmos de orientación y de identificación imaginaria a través de los cuales la fantasía del hombre construye las imágenes artísticas de su identidad antropológica.

Todo este componente imaginario del cuadro, como del poema, otorga al componente material-textual su definitiva orientación hacia la resultante de poeticidad o de esteticidad. En tales términos cooperan y se complementan de manera solidaria e indefectible las estructuras objetivo-materiales del texto y las subjetivo-comunicativas, pragmáti- 
cas, del acontecimiento artístico. La aclaración, por tanto, de las peculiaridades estructurales del texto artístico, así como de las antropológico-imaginarias relativas a la creación y recepción, aproximan poderosamente a la comprensión explícita de la esteticidad de la obra de arte.

Dentro de la estructuración del desarrollo imaginario en las artes plásticas cabe introducir una distinción análoga a la que se puede hacer también, a nuestro juicio, en la construcción imaginaria de la poesia, entre un componente gramatical o más propiamente sintáctico y un componente semántico. La diferenciación no es, según creemos, puramente externa o metafórica, sino que se corresponde exactamente con los procesos efectivos y reales del comportamiento de la imaginación en la producción y recepción de los textos plásticos. Y puesto que esta bipartición metodológico-especulativa deforma la realidad, comprimiéndola con violencia en el apriorismo de sistema de prejuicios teóricos, ofrece entonces una base poderosamente sintética y sistemática para la descripción integral de los productos artísticos, al extender también con propiedad al espacio imaginario las mismas categorias gramaticales y semánticas que organizan los respectivos niveles principales en el esquema semántico textual-inmanente.

Naturalmente que, al fijarse como objeto de análisis una unidad estructural compleja, un cuadro o un texto de arte verbal, cada uno de los dos componentes imaginarios, sintáctico y semántico, se ha de ver subsidiariamente descompuesto en dos espacios de extensión progresiva, micro- y macrocomponencial; según los presupuestos y exigencias técnicas habituales en las aportaciones de los gramáticos formales de ámbito textual. El principio que introduce el límite práctico donde se separan las consideraciones sintácticas o semánticas propias de cada uno de los componentes micro- y macroestructurales de la obra plástica, será en todo equivalente al que establece la misma divisoria en los discursos comunicativos, literarios y poéticos en lengua natural. Esto es, el alcance de las consideraciones microcomponenciales no rebasa nunca el límite de la sentencia o de la secuencia sentencial, sin necesidad de afrontar el contexto interior global del texto como unidad. Por el contrario, el ámbito de las operaciones analíticas macroestructurales afectará necesariamente a la estructura global del texto. (Albaladejo Mayordomo; García Berrio, 1983).

En la construcción imaginaria, la estructuración sucesivo-simbólica del mito equivaldría en todo al macrotexto narrativo. Si bien muchos podriamos establecer, en especial en relación al frecuente género de los textos plásticos de constitución más descriptiva-evidencial que narrativa, la propuesta de unos macro-simbolos, del tipo de la espada, la rueda, la copa o el escudo, etc..., descritos en la antropología imagi- 
naria como verdaderos esquemas de agregación simbólica, o archiconstituyentes ejemplares de los varios regímenes: diurno, nocturno y copulativo. El macrosímbolo correspondería así al tema central del cuadro como constituyente macrosemántico central, que a su vez agrupa y aglutina a la variedad de elementos simbólico-semánticos marginales, temas secundarios y detalles simples.

La pintura clásica desarrolló toda una serie de técnicas bien conocidas para evidenciar la función semántica central del tema. Piénsese, por ejemplo, en la gradatoria de nitidez luminoso-cromática y de disposición de gestos y actitudes de los varios personajes que aparecen en el cuadro de Velázquez, «La túnica de José» del Escorial. La túnica constituye el vértice del ángulo donde se inflexiona de una parte la serie de la presentación protagonizada por las expresiones mendaces y los gestos y actitudes convergentes en el destrozado lienzo, el cual es, a su vez, objeto del engaño y centro simbólico de la historia narrada míticoimaginaria. El otro vector de convergencia en el lienzo correspondería a la serie plástica de la angustia representada por el obscurecido Jacob, cuyo estado de sobresalto y zozobra está subrayado de una parte por el desvanecimiento de la luminosidad cromática y el relativo desdibujado de las formas, así como por el báculo caído, eficaz anécdota con el perrillo del primer plano, que expresan la tensión emocional del instante. Además cada uno de los constituyentes simbólicos del macrotexto que acabamos de enumerar, es susceptible, en sí mismo considerado, de consideraciones plástico-simbólicas singulares e individualizantes. Así es por ejemplo, la propia realización plástica del perrillo, o la portentosa anatomía de la espalda bañada en luz que constituye el verdadero foco plástico de la obra. Se entraría con tal tipo de observaciones en el dominio de lo microestructural, desconectado de la totalidad de la obra como conjunto. Es decir, alcanzaríamos una dimensión semántico-simbólica autoconstitutiva y personal, y si se quiere microsemántica o marginal con relación al tema central.

Adviértase, sin embargo, que en gran parte los procedimientos antes descritos para evidenciar el tema o estructura macrosemántica del cuadro son de naturaleza relacionante-sintáctica, esto es macrodispositiva. En el peculiar discurso de la pintura los símbolos parciales orientan hacia la simbolización global y textual de la obra en virtud de procedimientos canónicos de construcción sintáctica. Por esa ordenación macrosintáctica de la lectura del cuadro podemos deducir con toda claridad el contenido temático-anecdótico de «La figura de Vulcano", mientras que fundamentalmente por las mismas razones estructurales que perturban la recepción, resulta más problemática y escasamente monosemizable la lectura de «Las hilanderas». 
Por supuesto que la macrosintaxis textual en la obra plástica no debe ser tenida en cuenta sólo como un instrumento subsidario de la semántica. Cuenta ciertamente, de una parte, su condición deicticotemática y su capacidad de alojar y conducir las constelaciones de conceptos y de símbolos microestructurales en el interior del cuadro. Pero también la construcción de la obra pictórica, por la indole estrictamente plástica de su naturaleza, establece unas propuestas de interés fundamental, primario, para la relación pragmático-comunicativa de la lectura, del examen visual del cuadro. En esas operaciones de alojamiento de los singulares ritmos de lectura visual de la obra consiste seguramente lo más peculiar, y tal vez lo decisivo, de la sensacion estética de la pintura como arte.

El fundamento de muchas de las propuestas de vanguardia informalistas y abstractas reside precisamente en esa probabilidad de justificar autónomamente la lectura del cuadro como constatación dinámica de su macrosintaxis plástica. Ese recorrido óptico sobre las «estructuras preferenciales" de la obra en presencia, subsiguientes al juego de propuestas plásticas de los discursos de masas cromáticas y de sugerencias deícticas de los grafismos, permite considerar la lectura de los estructurados cuadros de Luis Gordillo sin ningún género de esfuerzos ni distorsiones de su naturaleza macrosintáctica, sobre los mismos presupuestos básicos de lectura que cualquiera de las pinturas clásicas de transferencia monosémica conceptual. Existirá, sin duda, en las composiciones de Gordillo un género de pretensiones comunicativo-simbólicas muy diferentes de las que animaban el arte clásico. Su necesidad expresivo-mimética se ha visto en la voluntad de rescate simbólico de los contenidos más introspectivos en la obra de Gordillo.

Sin embargo, ese desplazamiento del tipo de intereses referenciales en Luis Gordillo, como en general en la pintura moderna desde las revoluciones antimiméticas iniciadas por Braque y Picasso, trata de ganar espacios subconscientes y zonas intimamente borrosas de la sensibilidad inédita para el naturalismo objetivo de la plástica tradicional europea. Pero no se ha visto en la necesidad de alterar nada sustancial en el conjunto de los instrumentos sintácticos y en los códigos de lectura visual de las escuelas precedentes, dentro del universo de la construcción del mosaico plástico del texto pictórico.

Conviene profundizar más, a nuestro juicio, en la trascendencia simbólica de las propuestas macroestructurales para la lectura visual del texto plástico, como deliberadas estructuras preferenciales de la construcción textual. Si el cuadro fuera sólo la casual estructura de componentes plásticos espontáneos que muchos pintores confiesan, seguramente la pintura no sería, como lo es, un arte entrañable y tras- 
cendental. Es evidente que en la espontaneidad estética de los mismos instrumentos, en la positiva capacidad de impacto sensorial del cromatismo, como en las posibilidades inconscientes de liberación y de comunicación sentimental de los grafismos espontáneos, residen buena parte de las virtualidades del arte de la pintura. Por eso es explotación inteligente y diestra de unas posibilidades extremas e intimas puestas por la naturaleza objetiva a disposición de esta modalidad de la comunicación estética.

Pero la pintura, en esta escala de la sintaxis macroestructural, alcanza su genuina significación por la vertiente que aloja los ritmos materiales de expresión y de lectura en una sintaxis imaginaria vinculada al esquema textual del cuadro. Así es, en efecto, como los valores más inmediatos y aparentes de gracia ocasional y superficialidad mecánica, en sí mismos valiosos pero insuficientes en su propia intrascendencia, descubren su genuina condición de expresividad antropologica. Es lo propio del hombre la necesidad de orientar su entidad en la existencia. Tal necesidad entitativa de orientación recubre dimensiones básicas de la consciencia humana: tiempo y espacio. Todas las conjeturas depresivas sobre la angustia existencial tienen a la dimensión temporal como medida protagonista. La conciencia reversible de la posesión del hombre sobre y por el tiempo regula buena parte de los mecanismos de las ansiedades e incógnitas existenciales. (García Berrio, 1984).

El espacio se propone también, a su vez, como medida privilegiada de la progresión de la conciencia vital en cuanto orientación del hombre en su sistema de coordenadas, espacio-temporales, sobre las que teje y elabora su conceptuación imaginaria del universo. En este sentido, la relación en el texto del cuadro y en el del poema de los dos sistemas de coordenadas combinados ofrece cuantiosas evidencias. En un pintor como Antonio Saura, en quien, al igual que en el caso de vordillo y de Brinkmann, la conciencia postural diurna resulta muy desvanecida (Saura, 1980), toda forma que pueda traducir esquemas de verticalidad restituye inmediatamente el principio de afirmación estable de lo nitido y evidente diurno-postural sobre las involuciones ciegas del caos digestivo. De esa manera, los «personajes» de Saura, sus famosas series sobre Felipe II o sobre «Dora Maar», arrancan desde la inevitable condición de afirmación vertical de la estructura objetiva del referente. $Y$ es a partir de ese principio de afirmación postural que aloja incuestionable aunque remotamente en el universo de verdades históricas, objetivas y referenciables, este género de sus construcciones plásticas, como Saura puede dar salida después a su interpretación torturada, ondulatoria, caótica, del contrasentido. Contrapuestos senti- 
dos estructurantes de la orientación espacial imaginaria crean, por tanto, el poderoso efecto expresivo de estos cuadros de personajes.

La verticalidad obligada del modelo introduce, pues, el esquema de las referencias más nítidas. Un sentimiento de orientación espacial diurna y postural sobre lo concreto nos asegura, sólo muy parcial y marginalmente en el caso de Saura, en el universo de referentes constatables y distintos. Nos encontraríamos, por tanto, ante la primera forma de compromiso entre una dimensión de orientación espacial, la verticalidad, y un tipo de sensaciones fantásticas, las posturales, muy escasamente representativas con todo, como hemos dicho, en la voluntad expresiva de este artista. Un signo del espacio, por tanto, traduciendo un tipo de sentimientos y de consciencia imaginarios, el dominio de la realidad inmediata adquirido como conjunto de estructura de percepción temporal.

Pero las peculiaridades imaginario-constructivas de los personajes de Saura no las aporta la certeza postural del esquema vertical de partida del referente. Por el contrario pugna éste, en exigente dialéctica, con toda una confabulación nocturna y visceral distorsionante, que aporta a estas obras la evidencia más superficial de sus tantas veces ya evocada violencia. En la estructura corporal de los personajes de Saura y singularmente en los rostros, todo se distorsiona; toda regla congruente de organización anatómica o fisiognógmica queda abolida. Los ojos se desalojan de sus órbitas naturales, las bocas se desencajan en poderosos efectos de gesticulación desmesurada, de violencia agónica. Exagerando el ejemplo picassiano, el perfil de narices y de orejas ajusta sus propias sugerencias tan sólo a las necesidades plásticoemotivas de la representación simbólica. Como en Miró, miembros y sexos se ven con frecuencia hipertrofiados y desalojados de su colocación natural. Un vértigo desorganizador de la anatomía revuelve los atributos naturales de los personajes de Saura. Tal vez el efecto perceptivo más inmediato pueda ser el de la sangrante violencia, pero el más certero es seguramente el del caos de la disolución nocturna y el desorden digestivo.

La poética esencialmente nocturna de Saura se aloja y manifiesta, por tanto, en el seno de cualquiera de sus estructuras más sólidas y estables de orientación postural, pugna con la verticalidad de sus retratos, y triunfa incluso del orden doblemente sustentado en las coordenadas conjugadas de sus "Crucifixiones». Sin embargo otro orden de representación plástica particularmente expresivo de este pintor proclama el triunfo de la distorsión caótica de lo digestivo; se trata de sus conocidos cuadros de «multitudes» o muchedumbres. En estas sugerencias arracimadas de rostros descompuestos, de cabezas e insi- 


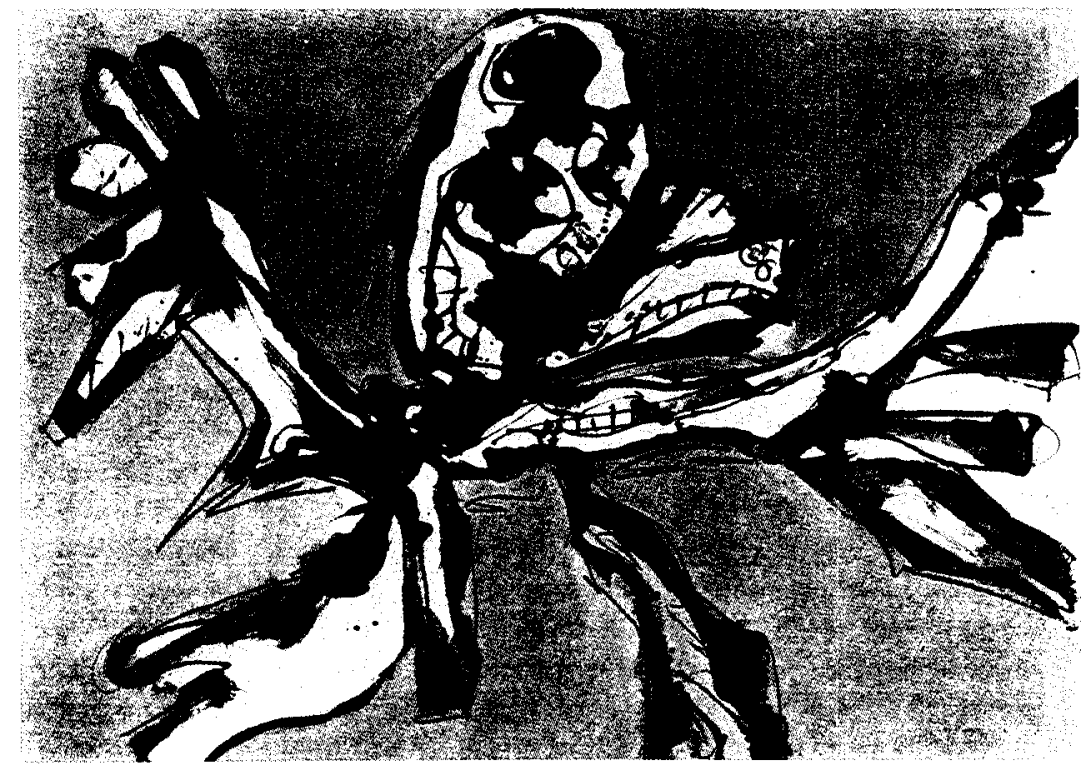

ANTONIO SAURA "Crucifixión»

nuación de cuerpos en violenta proximidad polémica, dentro de un cerrado espacio de amontonamiento, los sentimientos de polémica social diseñan su traducción más inmediata. Crueles mescolanzas, encuentros conflictivos de existencias e intereses, que configuran para la expresa conciencia de Saura sus opiniones sobre la historia y la organización social de los hombres. Pero, antes y después que esa conceptualización se abra paso en nuestro espacio consciente, las masas plásticas de las "muchedumbres" en descomposición inorgánica han conseguido expresar y comunicar sus específicos sentimientos de deconstrucción radical. Una respuesta universal caótica contra cualquier forma de afirmación radical estable y definida. La transcripción gráfica de un estado de vivencia preconsciente, abierto al vacío de no ser y a la opacidad total de la noche, dispone el cuidadoso azar de esas muchedumbres que avanzan amenazadoras y englobantes hacia los temores más íntimos del espectador sobrecogido.

Son hechos ya bien conocidos y tradicionalmente señalados las varias fórmulas y estructuras de construcción plástica del cuadro; tanto como el fenómeno de los varios ritmos de «ectura de la obra pictó- 
rica», más recientemente señalado y explotado por los sicólogos de las artes y los teóricos de la percepción visual. Un poco más adelante y muy ilustrativo consiste en señalar la doble naturaleza sintáctica, constructiva y receptora, de esos movimientos visuales, asociados a muy determinadas formas de acoplamiento de los biorritmos, entablados sobre esquemas fundamentales de configuración antropológica en el entendimiento y la orientación del cosmos. Vale la pena, en consecuencia, reflexionar sobre la transferencia imaginaria de los varios esquemas conocidos y descritos de la construcción textual del cuadro a las formas elementales, en las que se expresan las coordenadas de orientación antropológico-espacial del hombre como rigurosa y peculiar sintaxis imaginaria.

Pensemos a ese respecto en la contraposición tantas veces explotada entre el Greco y Velázquez, dentro del incierto entendimiento y el problemático deslinde entre las actitudes manierista y barroca. Lo que en ellos se opone estructuralmente es mucho más que dos recetas concretas de construcción del cuadro, dos sistemas de preferencias compositivas. En Velázquez el predominio de las secuencias horizontales, centradas o en convergencia y abiertas en expansión, gobierna paradigmáticamente el ritmo de lectura y de afirmación imaginaria, no sólo en sus obras mayores y mejor conocidas, como las ya aludidas «La túnica de José" o "La fragua de Vulcano», "Las lanzas», "Las hilanderas», «Los borrachos» O "Las Meninas». Mientras la mirada discurre complacida sobre las suaves ondulaciones, modulaciones carnales de la reclinada "Venus del espejo». Nada en Velázquez propone el esfuerzo de elevación ascendente; ni siquiera la estructura natural de sus retratos, incluso los ecuestres: la mirada de éstos es siempre directa, vertical, de arriba abajo. Así se organizan los del Conde Duque de Olivares o el del Príncipe Baltasar Carlos y las representaciones apicaradas de los filósofos antiguos Esopo y Menipo; mientras que la ponderación de los trajes desplazados de las reinas Isabel y Margarita, o la propia corpulenta apostura de los retratos de Felipe IV o del Conde Duque en pie confirma una línea de afirmación horizontal, en poderoso despliegue que no desmentirán retratos posteriores como los de Juan de Pareja o Inocencio $X$.

Una tendencia arraigada por tanto, que transcribe la inalterable conciencia de la visión, desde los tempranos cuadros de dialéctica narrativa y horizontal: «El almuerzo» o «El aguador de Sevilla». Ni siquiera el tematismo de la glorificación religiosa impone la elevación de este terrenal y delicioso universo plástico velazqueño. Sumisa y humilde, recogiendo en gracia de modestia la tentación de estilizaciones sublimes, es la apostura de su temprana «inmaculada" con la mirada 
refugiada en tierra, igual que la otra, cegada, de su magistral «Cristo en la cruz", que contraviene incluso los usos arraigados de una iconografía de la expiración, con la mirada vuelta al cielo, la cual le era próxima y familiar en las propuestas teóricas y prácticas de su suegro Pacheco. $\mathrm{Ni}$ la "Coronación de la Virgen", ni la «mposición de la casulla a San IIdefonso" se deslizan tampoco por esa naturalísima tendencia a la elevación apoteósica. Velázquez centra a sus santos en un despliegue horizontal, a la vez terrestre y espontáneo, como sitúa con delicada simpatía la obligada horizontalidad de sus enanos bufones: el niño de Vallecas, Calabacillas o El Primo.

Análoga voluntad espacializadora, aunque contrapuesta, explica el sentimiento fantástico de elevación sublime que informa, casi invariablemente, las construcciones manieristas del Greco. Ni siquiera el indudable peso de las anécdotas lastrantes en la base de sus textos más famosos, como «El Expolio», o "El entierro del Conde de Orgaz", puede contrarrestar la sugerencia fantástica de elevación en la que todos los elementos icónicos se confabulan, desde la misma estilización de cuerpos y rostros, particularmente perceptible en parejas de santos como en los cuadros de San Andrés y San Francisco, en el de San Juan Bautista y San Juan Evangelista, o en el rostro inverosímilmente distorsionado de su ascético «San Jerónimo, cardenal» de la colección Frick de Nueva York.

No se puede justificar en la estructura material de las construcciones estrictas la sensación de impulso ascensional del Greco. A veces se trata de una leve insinuación de algunas miradas y gestos decisivos, como en algunos personajes del cortejo fúnebre de «El entierro del Conde de Orgaz». Regularmente refuerza esa impresión la desvinculación y el desinterés casi absolutos de los protagonistas de la escena celestial con relación a la contingencia de los acontecimientos terrenos, como se descubre en «El bautismo de Cristo", en contraste con la permanente deixis de elevación en la orientación de sus personajes y grupos terrenales, como los dos protagonistas del cuadro «Julián Romero de las Azañas y San Julián», o los integrantes del «Pentecostés». Los movimientos del pincel, el flujo de los paños revueltos en ropas y estandartes, la insinuación constante de las picas y hasta de banderas, la estilizada robustez de los protagonistas y sobre todo la presencia constante de un término de tensión ascensional: son todos medios que subrayan un paraiso cenital, que no gravita sobre la tierra, sino que atrae hacia sí a personajes y anécdotas históricas en tensa levitación.

Prescíndase de esa doble orientación imaginaria, y el estilo plástico y la impregnación espiritual de los dos grandes pintores españoles no encontrará seguramente su más radical y esquemática fórmula de defi- 
nición. La sintaxis imaginaria, por tanto, el esquematismo de orientación espacial fantástica, gobierna, tal vez por encima incluso de los propios simbolos semánticos de la representación iconográfica, la modulacion estilistica más íntima de los grandes pintores, como los son Velázquez o El ìreco.

Entre los pintores modernos españoles, cuyas obras venimos examinando con mayor asiduidad, también el estilo de Luis viordillo se presenta fuertemente dependiente de la peculiarizacion de una sintaxis Imaginarı. Es precisamente la insobornable complejidad del trazado de sus redes compositivas lo que caracteriza de manera muy marcada la fisonomía plástica de sus obras con más importante empeño. Parte iordillo de una compleja textura de dipujo involuntario, a través del que se expresan sus puisiones subconscientes (Calvo serraller, 1984). El trapajo posterior de reactivacion plástica y material en la estructura definitiva del cuadro al recubrir y enmascarar las líneas del dibujo, no desvanece, contra 10 que comunmente se afirma, su verdadera huella intencional. Persiste la sintaxis del texto a través de las indicaciones indırectas, obliteradas, del primitivo dipujo como una red de rumbos exactísımos, que conmociona y moviliza invarıademente los símbolos, las unidades semánticas de la construccion.

El movil trazo que vincula símoolos y espacıos cromátıcos elegıdos del cuadro en las diversas realizaciones de las series recientes «Mosalco" o "Sobre Dlanco" no diferencla en gran manera sus procedimientos de conduccion para los ritmos de lectura, del recorrido forzado entre los lunares, llenos o vacíos, de la serie "uiruyere». La movilizacion sintáctica de trazos explícıtos y de propuestas contrastadas con vincuIacion implícita, constituye sın duda uno de los rasgos más caracteristicos en el estilo personal de Luis viordillo. Sobre la inconfundible sugerencia de afirmacion y el poder de sus representaciones semánticosimbolicas, esa singular capacidad de señalar y hacer notar los ritmos gráficos del cuadro aporta el componente más peculiar al discurso de este artista.

La sintaxis imaginaria, instrumento de afirmacion y protocolo de encuentro rítmico en la lectura de la obra, se afirma en consecuencia como una de las instancias más responsables en la configuracion artística del interés de cuadros y poemas. Sintaxis que vincula, de una parte, los símbolos del material concreto, estableciendo sus constelaciones, dependencias y solidaridades recíprocas. Pero que, además, instrumentaliza esa necesaria dinamización de la semántica inerte al servicio de un juego misterioso de afirmaciones espaciales, donde el hombre descubre sus ritmos de orientacion antropologica más necesarios e íntimos. 


\section{Semántica imaginaria de los símbolos plásticos}

Lo mejor conocido hasta ahora del constituyente imaginario en los discursos artísticos es sin duda la dimension de sus simbolos, de sus aportacıones plásticas y consistentes. En el arte clásico y tradıcional la iconologia ha estaplecido repertorios seguros de formas de representacion, acotadas por siglos como convenciones necesarias para la lectura y el entendimiento economico de las opras plásticas. La preceptiva literaria y los paradigmas de descripcion retoricos, por otra parte, han realızado un trabajo equivalente, si pıen más genérico e inconcreto como corresponde a la naturaleza más movil e inestable de los opjetos veroales. Por ultimo el sicoanálisis crítico desde Jung a Bachelard, secundado por la mitocrítica y la antropología de la imaginacion, han convertido los repertorios iconologicos y retoricos a paradigmas de expresion simpolica perfectamente normalizados y articulados en los posioles regimenes: diurno-postural, nocturno-digestivo y amorosocopulativo.

En correspondencia con esa situacion, el análisis simbolico de las figuras de la poesía y de las constantes iconicas de la pintura creo que, siendo muy necesario e importante, reserva ya menos sorpresas a la investıgacion, que los paradigmas resultantes de la sintaxis imaginaria. Una sintaxis que puede ser entendida, bien sea como un algoritmo de constelación espacial simbólica extendido en el dominio del texto (Burgos 1983), o Dajo la forma, más proxima a nuestros propios intereses, de la capacidad de simpolizar e inducir las representaciones. Entendemos aquí por espacializacion el principio de orientacion antropologıca más elemental y básico, mejor arraigado por tanto que el sistema de la acongojada búsqueda humana perceptible en las metáforas de temporalidad.

Sin embargo, tal vez uno de los rasgos más peculiares de la pintura $y$ en general del arte moderno puede situarse en la potenciación de capacidad simbólica, que ha llegado a conquistar sacrificando las formas más escuetas de concreción referencial en los repertorios iconográficos tradicionales. Hemos aludido ya al efecto indirecto, curioso y hasta paradójico que produce la ampliación de las capacidades generales de significación del arte arreferencial abstracto. En la medida en que la abstracción representa menos inmediatamente las formas concretas y tangibles de la realidad, crecen sus posibilidades de sugerencia polisémica, sobre dominios de la realidad menos inmediatos y más recónditos y espirituales. De forma equivalente, la necesaria universalidad del símbolo sobre la representación de las entidades concretas que él recubre, se ve más fácil y eficazmente ejecutada mediante la práctica 


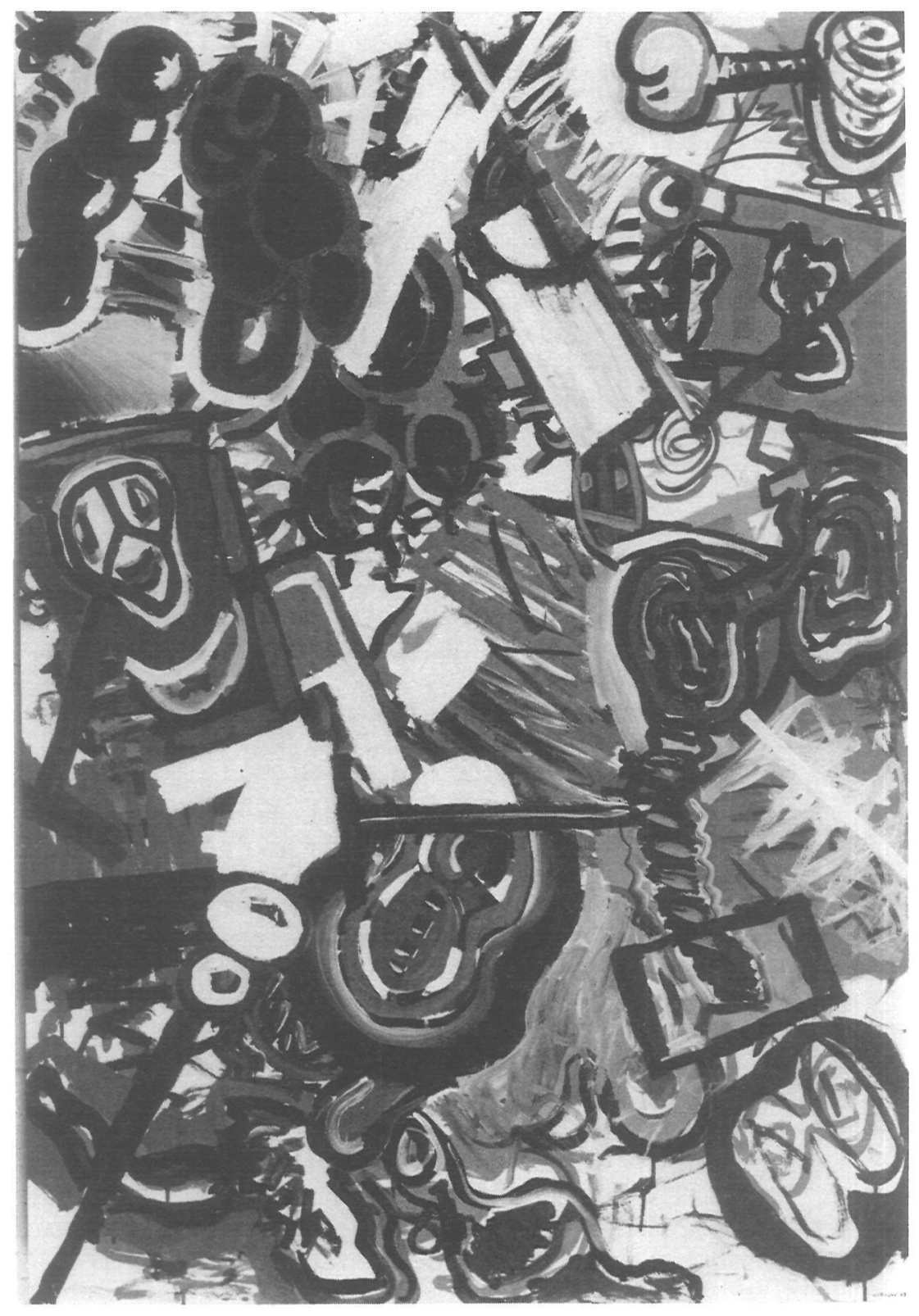

LUIS GORDILLO “Mosaico B» 
de la abstracción, y en general a través del conjunto de libertades con la mimesis del modelo, que caracteriza a la pintura moderna.

El arte tradicional de Occidente demandaba sin duda una costosa exigencia de colaboracion convencional para convertir los modelos en arquetipos. Cuando Rembrandt trata de representar a su madre como profetisa, o de transformar personajes de su entorno real como Saskia o Hendrickje en arquetipos bíblicos o mitológicos, persiste siempre la firme vinculacion del modelo concreto a la referencia personal conocıda. De esta forma se debate a proposito de "La sibila» de Velázquez, el que sea o no retrato de la propia mujer del artista. La mediación mimética de la referencia distorsiona poderosamente la capacidad de generalizacion del arquetipo clásico. Por el contrario, las metamorfosis cubistas picassianas en «Las señoritas de Aviño" o la tensión expresionista de los personajes de Jawlensky, de Kirchner, de Otto Müller, o de Emil Nolde, les permite automáticamente potenciar la universalizacion simbolica de sus representaciones. Siendo la abstraccion más pura en las expresiones más evolucionadas de la tendencia, como son las de un pintor como Lucio Muñoz, por ejemplo, donde los poderes de sugestıon sımpolıca se despliegan en la lipertad de sus más altas posibilidades.

En la medida en que los símbolos plásticos del arte moderno debiIItan sus conexiones con las formas concretas de la referencialidad, aumenta la riqueza semántica de los discursos. Así la sujeción últimamente mımétıca deı surrealismo de Dalí, o las criaturas realísimas - María y otros-- que habitan el espacio mágico de Antonio Lopez, acotan en necesaria restriccion las posibilidades de cooperacion de la semántıca ımagınarıa en la articulacıon de sus simbolos. Algo equivalente, aunque obrando de forma distınta, contribuye a oponer el universo sımpolico de Antonio saura, más acotado en las artıculaciones de su referencialidad historica frente a la inagotable fertilidad que comunıca el unıverso plástıco de Luıs viordıllo. En tal sentıdo, resulta portentosa la liberación plástıca de un onırısmo tan cırcunstanciadamente monumental e incluso arqueologico, como es el que soporta la amDientacion espacial de muchas elegantísımas construcciones de José Hernández.

La delıperada y voluntarıa sujeción a referencia estricta que Saura viene practicando en sus conocidas series mayores - Felipe II, Quevedo, el perro de lioya, Dora Maar, Brigitte Bardot, etc...- ha contripuldo no poco a favorecer la difundida objeción contra este pintor de un grado de relativo empobrecimiento simbolico, a causa de la reiteracion de una escasamente variada galeria de representaciones iconicas. Tan que superficial opinión corrobora, sin embargo, nuestra tesis sobre 
ei grado de liberación imaginativa aportada por la libertad simbólica en la pintura moderna. Sin duda que el universo plástico de saura ha de juzgarse al interior de sus personajes, y no por sus perfiles más externos y por sus formas iconográficas más reconocibles. La variacion de formas de sangrienta tensión y de violencia que comunican, por ejemplo, los cuadros de la serie sobre Felipe II es una realidad plástica innegable, que se nos impone desde la libérrima variabilidad plástica con que se constituye y expresa la conformacion visceral del personaje. No hay duda, por eso, de que los personajes-símbolo de saura constituyen sólo la propuesta de un «marco», el acotamiento convencional de un espacio para el paroxismo de la expresividad gestual dentro del espacio general del lienzo. Pero al mismo tiempo, no se puede rechazar tampoco que por sus propias propuestas, el perfil convencionalizado del «marco» restringe en cierta medida la operatividad imaginaria de la fantasia.

Este «manierismo» - pintura sobre pintura-programático de los símpolos de saura, muy comun por lo demás - salvadas las apariencias - al de la mayoría de los pintores modernos, podría servir para contraponer un género de simbolizacion tradicional o iconográfico de la semántica imaginaria, al tipo más libre, inédito y antropológico de los símoolos, segun se practican más excepcionalmente en pintores como Luis Gordillo. El tipo de reparos a las reiteraciones semánticas más evidentes en los personajes de Saura, del que antes nos hacíamos eco, se podría restringir muy drásticamente, cuando, reducidas a paradigmas estructurales y encauzadas en sus estimulos históricos, gran parte de las apariencias de diversidad revolucionaria de la pintura moderna, se redujesen a una nueva iconografía «sui generis» de variación retorica de los símbolos.

En distintos lugares hemos protestado ya contra la parte de superficialidad falaz que se esconde en las atractivas propuestas del arte «apierto" y la "estructura ausente» como razon diferencial de un arte moderno con pretensiones anticlásicas. En la misma medida, hemos reclamado la urgencia de una rigurosa retorica de la poesía y la pintura modernas, concebida como inventario operativo de las unidades y los paradigmas simbólicos que se reiteran y reconocen inevitablemente en el desarrollo del arte moderno. En esa reiteración seguramente involuntaria e inconsciente, pero sin duda que también efectiva e inevitable, se ven construidas la mayoría de las poéticas individuales de los diferentes creadores, quienes repiten con más voluntad razonable de discrepancia que con efectiva capacidad de renovacion, una combinatoria altamente economica de soluciones simbólicas incapaces de escapar a la reiteración histórica. En tal sentido una opción semántica conven- 


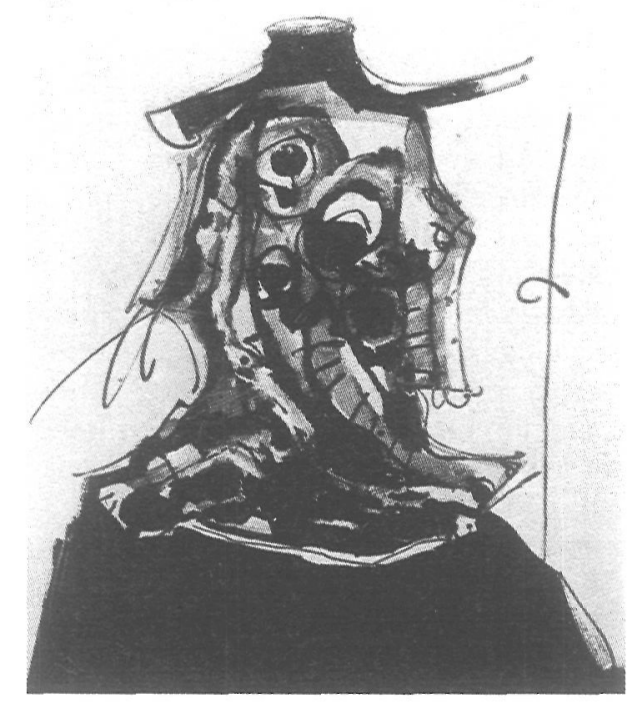

ANTONIO SAURA «Portrait imaginaire de Philippe \|»

cional como la de Saura, no se diferencia mucho en el fondo de la práctica encubierta en la mayoría de los sistemas expresivos de la pintura moderna.

El arte actual propende a la exaltación individual del símbolo. No los mezcla como hacía el clásico, combinándolos en la construcción de escenas. Esta ha sido una característica bastante común de la pintura moderna, que alcanza tanto al simbolismo de la figuración, como al del arte abstracto. La representación simbólica individualizante rompe el diálogo narrativo en el interior del texto. La necesidad narrativa de los retablos y de las historias ilustradas por el Giotto en Asís o por Sánchez Cotán y el martirio de los frailes en la Cartuja de Granada, ha sido rareza exótica en el arte moderno hasta hace bien poco tiempo, tal vez con la excepción del simbolismo surrealista más plural de Dalí o en la actualidad con las sugestivas evocaciones fantásticas de José Hernández, que imponen un sentimiento de procesualidad misteriosa. Pero la narración como proceso enunciado vuelve a adquirir protagonismo en la actualidad, recuperada en muchos relatos plásticos de los «anacronistas italianos", y forma parte también de un sector característico en las poéticas españolas de la «postmodernidad». Con la articulación 
narrativa de los símbolos la pintura deviene «mito»; esto es, secuencia historial simbólica.

Esta modalidad mitológica de la pintura moderna española tiene sus antecedentes y estímulos inmediatos en la seriación de imágenes de Luis Gordillo, pero ha encontrado su propio nombre en la obra de Pérez Villalta. Este joven artista ha abierto a una radiante inocencia postural de conciencia los presentimientos mágicos de aquellos habitantes entrevistos en los espacios familiares de Antonio López, o en las suntuosas ensoñaciones nocturnas de José Hernández. La mitología plástica de Pérez Villalta no añora ni remeda, contra sus apariencias más superficiales, los mitos clásicos helénicos, al menos no en términos de su recuperación emocional histórica. Su encuentro con personajes y mitos griegos viene marcado, a nuestro juicio, por la fatal convergencia en una atmósfera de claridad casi racionalista. Una diafanidad, cifra de lo abierto y de lo inmediato, que tiene en las transparencias luminosas de la mediterraneidad la condensación de su ámbito mítico.

En conclusion, creemos haber probado en este artículo la posibilidad real y no meramente metafórica de un análisis semiótico comun a los textos plásticos y a los poéticos (García Berrio, 1981a). La posibilidad de enjuiciar, explicar y aclarar esos dos universos de discurso, el verbal y el de la argumentación plástica, prueba un principio más necesario e importante aún que el de las más inmediatas constataciones metodológicas. Lo que posibilita definitivamente el comodo tránsito y las transferencias no forzadas entre objetos artísticos arraigados en medios materiales diferentes, creemos que es la gravitación inexcusaole sobre ellos de los universales estéticos.

Nada más alejado, por tanto, de las vigentes tentaciones del relativismo pragmático. El texto artístico, desde modalidades de ejecución material muy distintas, canaliza sin embargo procesos de adquisición y de expresión estética con poderosas constancias: la simbolización del caudal de experiencias imaginarias que se ordena y consolida en «regímenes antropologicos fantásticos" y en constantes de orientación espacial. Coordenadas profundas, radicalmente esquemáticas, recubiertas de las delicias cognitivas y sentimentales de la vivienda artística; y éstas, a su vez, servidas por el halago sensitivo de las formas más inmediatas de los textos artísticos. 


\section{Referencias bibliográficas}

Bobes Naves, C. (1985), Teoría general de la novela. Semiología de la Regenta. Madrid, Gredos.

Burgos J. (1983), Pour une Poétique de l'Imaginaire, París, Seuil.

Calvo Serraller, F. (1984), Luis Gordillo, Madrid-Nueva York, Fernando Vijande editor.

Durand G. (1983), Estructuras antropológicas de lo imaginario, Madrid, Taurus.

Garcia Berrio, A. (1973), Significado actual del Formalismo ruso, Barcelona, Planeta.

- (1978), Historia de un abuso interpretativo: ut pictura poesis, en «Estudios ofrecidos a E. Alarcos Llorach», Univ. Oviedo, I, pp. 291307.

- (1980), Lingüística, literaridad / poeticidad, en "Anuario de la Sociedad de Literatura general y comparada", II, pp. 125-170.

- (1981), E. Brinkmann. Semiótica textual de un discurso plástico, Montpellier, Études sociocritiques.

- (1981a), Joan Miró. Texto plástico y metáfora de lenguaje, en Homenaje a Miró, "Cuadernos Hispanoamericanos", 369, pp. $1-31$.

- (1984), Antonio Saura. Espacio imaginario y tiempo del hombre, en «Revista de Occidente», 32, pp. 127-146.

- (1985), La construcción imaginaria en «Cántico» de Guillén, Limoges, Trames.

García Berrio A.; Albaladejo Mayordomo, T. (1983), Estructura composicional. Macroestructuras, en "Estudios de Lingüística", Univ. Alicante, I, pp. 111-163.

Hernández, T.; García Berrio, A. (1981), Imagen surrealista y metaforismo barroco, en «Analecta Malacitana», Univ. Málaga, IV, 1, pp. 67-103.

- (1984), La pintura de O. Sarachaga: esquema plástico y construcción imaginaria, Museo de Albacete.

Saura, A. (1983), La imagen pintada, Madrid, Galería A. Machón. 